\title{
ON A NEW BAT FROM MANCHURIA
}

\author{
By Arthur de Carle Sowerby, F. Z. S.
}

In the autumn of 1914, while on a collecting trip in the forests of North Kirin, Manchuria, on behalf of the United States National Museum, I secured a specimen of a Murina representing a form related to $M$. huttoni of northern India, but sufficiently distinct from the latter as well as from all other known forms from eastern Asia to warrant its being separated as a new subspecies of huttoni. 'The specimen was sent to the United States National Museum, where, in company with Mr. Gerrit S. Miller, Jr., of that institution, who passed on his notes to me, I was able to reexamine it. This new form may be known by the name:

Murina huttoni fuscus subsp. nov.

It may be described as a dusky brown form of huttoni in which there are numerous long hairs of a lighter color scattered through the pelt and extending on to the webbing between the tail and the hind legs as well as upon the feet. The under parts are slightly lighter than the upper parts.

It differs from true huttoni in being of a darker color, huttoni having been described as "light snuff-brown" by Hutton in 1872. There is, however, no detailed description of true huttoni. Peters described the upper incisors of this species as being separated from the canines as in suilla, of Java and Sumatra, his plate of the latter showing a wide and definite space quite unlike the narrow crack in the Kirin specimen.

The Kirin specimen differs from $M$. ussuriensis, Ognev, of the Ussuri region, in its larger size, its forearm measuring $40 \mathrm{~mm}$. instead of $32 \mathrm{~mm}$. It differs from $M$. hilgendorf, Peters, of Japan, in being larger, its head and body measuring $58 \mathrm{~mm}$. as against $50 \mathrm{~mm}$. There is no sign of the low sagittal crest present in hilgendorfi. From M. auratus, M.-Edw., of Tibet, it differs in its much greater size; from $M$. leucogaster, M.-Edw. (with which it agrees in general size) in its very different color, leucogaster having the entire upper parts "brun-châtain," and in the much less backwardly-projecting occipital region; from $M$. sibiricus in having the upper incisors proportioned as in leucogaster; and from M. rubella, Thos., in the absence of any red color.

It may be mentioned, incidentally, that $M$. ussuriensis and $M$. hilgendorfi have been secured in Manchuria, while $M$. rubella was described from Kuatun, in Fukien province, China.

Type.-Female, skin and skull, No. 199672, U. S. National Museum, taken in the forest of North Kirin, Imienpo area, Manchuria, September 28, 1914, by A. de C. Sowerby. Original number, 702.

Measurements.-Head and body, $58 \mathrm{~mm}$.; tail, $34 \mathrm{~mm}$.; ear, $18 \mathrm{~mm}$. ; forearm, $40 \mathrm{~mm}$. Skull.-Greatest length, $16.8 \mathrm{~mm}$.; zygomatic width, $10.4 \mathrm{~mm}$.; upper tooth row, exclusive of incisors, $5.6 \mathrm{~mm}$.; lower tooth row, $6.4 \mathrm{~mm}$.; lower jaw. $12.2 \mathrm{~mm}$. 
Color.-General greyish, or dusky brown, with no sign of reddish. Slightly lighter below, darker round the eyes.

The distribution of this new form is not at present known. Its presence in the Imienpo district so late in September, and the fact that the specimen described above was secured in the house of a Russian peasant, suggest that the species hibernates in this region.

Shanghai, China.

\section{DISPOSITION AND INTELLIGENCE OF THE ORANG-UTAN}

\section{By W. Henry Sheak}

It is difficult to say which of the two great apes, the chimpanzee or the orang-utan, is the larger. I have spent many years studying living specimens in captivity and the mounted skins and skeletons in museums, but I am not yet convinced in favor of either. It is probable, however, that the chimpanzee will average slightly taller than his Bornean cousin, but there is scarcely any doubt but what the orang will average considerably the heavier of the two. He is much more robust in his build.

I have talked with a number of men who have hunted these two anthropoids, and I have read all the literature available, with a result similar to that from my own personal observations. Doctor Hornaday's largest male of the species Pongo wurmbii (if wurmbii be a distinct species) measured $4 \mathrm{ft}$., 6 in. in height. A male of $P$. satyrus measured $4 \mathrm{ft}$. $4 \frac{1}{2}$ in., so that there is very little difference in size between these two. His largest female measured $4 \mathrm{ft}$. in height. Joseph S. Edwards, the well known exhibitor of rare animals, who has had extensive experience with the orang as well as with the chimpanzee, and who imported the first gorilla that ever reached the United States alive, tells me that his brother once sailed from Singapore with seventeen orangs and two of them were $5 \mathrm{ft}$. in height. According to Wallace, the stretch of arms of the largest orangs is $7 \mathrm{ft}$., $8 \mathrm{in}$. However it has been verbally stated to me that "Chief Utan," the great orang that lived in the Philadelphia zoölogical garden a few years ago and whose wellmounted skin now adorns the mammal hall in the Academy of Natural Sciences of Philadelphia, measured $8 \mathrm{ft} ., 4 \mathrm{in}$. from tip of fingers to tip of fingers over the outstretched arms. But I have not had the opportunity of verifying these figures. The weights of the largestadults range from 120 to 160 pounds. 


\section{$2 \mathrm{BHL}$ Biodiversity Heritage Library}

1922. "On a New Bat from Manchuria." Journal of mammalogy 3, 46-47. https://doi.org/10.2307/1373453.

View This Item Online: https://www.biodiversitylibrary.org/item/220041

DOI: https://doi.org/10.2307/1373453

Permalink: https://www.biodiversitylibrary.org/partpdf/90543

\section{Holding Institution}

Smithsonian Libraries

\section{Sponsored by}

Biodiversity Heritage Library

\section{Copyright \& Reuse}

Copyright Status: Not in copyright. The BHL knows of no copyright restrictions on this item.

This document was created from content at the Biodiversity Heritage Library, the world's largest open access digital library for biodiversity literature and archives. Visit BHL at https://www.biodiversitylibrary.org. 